\title{
Pelepasan Informasi Medis Kepada Pihak Ketiga Di Rumah Sakit (Literature Review)
}

\author{
Anastasyannisa Ramadhanty ${ }^{1}$, Nanda Aula Rumana ${ }^{2}$, Deasy Rosmala Dewi ${ }^{3}$, Noor \\ Yulia $^{4}$ \\ ${ }^{1,2,3,4}$ Program Studi Rekam Medis dan Informasi Kesehatan, Fakultas Ilmu-ilmu \\ Kesehatan, Universitas Esa Unggul, DKI Jakarta, Indonesia \\ Email: 1anastasyannisa43@gmail.com
}

\begin{abstract}
Medical record information is confidential which must be protected from leakage of data/information in accordance with the medical code of ethics and applicable laws and regulations. The release of medical information must follow the applicable procedures, this aims to protect the hospital from further demands. This study aims to describe the suitability of SOPs for releasing medical information to third parties, types of requests for release of medical information and constraints in releasing medical information using fishbone diagrams. This research is a literature review study using a sample of 11 journals. Search articles using the Google Scholar database. The results of the study found that the percentage of compliance with SOPs for releasing medical information to third parties in hospitals was the percentage of releases that were in accordance with SOPs between 66\%-82\%, while the precentage that did not match the SOPs was between 18\%-34\%. The types of requests for release of medical information are for the purposes of visum et repertum, insurance and education. Constraints in releasing medical information to third parties in hospitals using fishbone diagrams are mostly found in Man, especially in patients/patient families do not bring complete requirements.
\end{abstract}

Keywords: Release of Medical Information, Medical Record

\begin{abstract}
Abstrak
Rekam medis bersifat rahasia yang wajib dilindungi dari pembocoran data/informasi sesuai dengan kode etik kedokteran dan peraturan perundang-undangan yang berlaku. Dalam pelepasan informasi medis harus mengikuti prosedur yang berlaku, hal ini bertujuan untuk melindungi rumah sakit dari tuntutan yang lebih jauh. Penelitian ini bertujuan untuk mengetahui gambaran kesesuaian SPO pelepasan informasi medis kepada pihak ketiga, jenis permintaan pelepasan informasi medis serta kendala dalam pelepasan informasi medis dengan menggunakan diagram fishbone. Penelitian ini merupakan studi literaturereview dengan menggunakan sampel 11 jurnal. Pencarian artikel menggunakan database google scholar. Hasil penelitian ditemukan presentase kesesuaian SPO pelepasan informasi medis kepada pihak ketiga di rumah sakit yaitu pelepasan yang sudah sesuai dengan SPO presentasenya diantara 66\%-82\%, sedangkan yang tidak sesuai SPO presentasenya diantara 18\%-34\%. Jenis permintaan pelepasan informasi medis yaitu untuk keperluan visum et repertum, asuransi dan pendidikan. Kendala dalam pelepasan informasi medis kepada pihak ketiga di rumah sakit dengan
\end{abstract}


menggunakan diagram fishbone yang terbanyak terdapat pada Man, terutama pada pasien/keluarga pasien tidak membawa persyaratan secara lengkap.

Kata Kunci: Pelepasan Informasi Medis, Rekam Medis

\section{PENDAHULUAN}

Rumah sakit adalah lembaga yang menyelenggarakan pelayanan kesehatan perorangan secara paripurna yang menyediakan pelayanan rawat inap, rawat jalan, dan gawat darurat (Kemenkes, 2009). Dalam upaya penyelenggaraan pelayanan kesehatan yang paripurna, maka setiap rumah sakit diperlukan membuat penyelenggaraan rekam medis (Hatta, 2008). Rekam medis merupakan dokumen dan catatan yang berisi tentang identitas pasien, hasil pemeriksaan, tindakan, pengobatan dan pelayanan lain yang telah diberikan kepada pasien. Catatan rekam medis ini adalah milik sarana pelayanan kesehatan, namun isi dari rekam medis merupakan milik pasien dalam bentuk resume medis. Resume medis ini dapat diberikan, dicatat, atau digandakan oleh pasien atau orang yang diberi kuasa atas persetujuan tertulis dari pasien atau keluarga pasien. Namun, untuk keperluan pendidikan atau penelitian, pelepasan informasi medis tidak diperlukan persetujuan tertulis dari pasien melainkan persetujuan tertulis dari pimpinan sarana pelayanan kesehatan (Kemenkes, 2008).

Pada standar pelepasan informasi medis untuk keperluan pengklaiman asuransi, petugas rekam medis akan memeriksa keabsahan surat permintaan informasi secara seksama. Saat ini, proses tersebut seringkali tidak ada lagi, dan catatan rekam medis disalin begitu saja. Dan dalam pelepasan informasi medis harus mengikuti prosedur yang berlaku, hal ini bertujuan untuk melindungi rumah sakit dari tuntutan yang lebih jauh. Jika pelaksanaan pelepasan informasi medis tidak sesuai dengan standar atau ketentuan hukum yang berlaku, maka akan dikenakan sanksi seperti denda, pencabutan izin, dan bahkan hukuman penjara. Untuk itu pelepasan informasi medis harus dilakukan dengan benar dan sesuai dengan etika, standar, dan hukum (Depkes, 2006).

Sarana pelayanan kesehatan wajib menjaga keamanan dan menyimpan informasi medis yang terdapat pada rekam medis. Sedangkan pihak yang membutuhkan informasi medis harus senantiasa menghormati privasi pasien. Secara keseluruhan, privasi (privacy), kerahasiaan (confidentiality), keamanan (security), dan keselamatan (safety) adalah perangkat yang melindungi informasi di dalam rekam medis (bentuk kertas maupun elektronik). Rumah sakit sebagai salah satu sarana pelayanan kesehatan bertanggung jawab untuk melindungi informasi kesehatan yang terdapat di dalam rekam medis terhadap kemungkinan rusak, pemalsuan, hilang dan akses yang tidak sah (Hatta, 2008).

Berdasarkan hasil penelitian sebelumnya yang dilakukan oleh Permana \& Rumana (2017), ditemukan sebesar $24 \%$ pelaksanaan pelepasan informasi medis yang masih belum sesuai dengan SPO yang berlaku (Permana \& Rumana, 2017). Lapenia \& Masturoh (2019), dalam pelaksanaan pelepasan informasi medis masih belum sesuai dengan SPO yang berlaku (Lapenia \& Masturoh, 2019). Warijan \& 'Afifah (2019) dalam pelaksanaan pelepasan informasi medis juga masih belum sesuai dengan SPO yang berlaku (Warijan \& 'Afifah, 2019). 
Berdasarkan dari beberapa penelitian diatas dalam pelaksanaan pelepasan informasi medis masih belum sesuai dengan PERMENKES No. 269/MENKES/PER/III/2008 tentang Rekam Medis Pasal 10 ayat (1) menyatakan bahwa "Informasi tentang identitas, diagnosis, riwayat penyakit, riwayat pemeriksaan, dan riwayat pengobatan pasien harus dijaga kerahasiaannya oleh dokter, dokter gigi, tenaga kesehatan tertentu, petugas pengelola dan pimpinan sarana kesehatan" (Kemenkes, 2008). Dan juga dengan Undang-undang RI No. 29 Tahun 2004 tentang Praktik Kedokteran Pasal 47 ayat (2) menyatakan bahwa "Rekam medis harus disimpan dan dijaga kerahasiannya oleh dokter atau dokter gigi dan pimpinan sarana pelayanan kesehatan" (Kemenkes, 2004).

\section{METODE}

Penelitian ini menggunakan desain literature review dengan menggunakan sampel 11 jurnal yang membahas mengenai pelepasan informasi medis kepada pihak ketiga di rumah sakit dan pencarian literatur ini menggunakan database Google Scholar. Kriteria inklusi untuk menilai jurnal yang akan dipilih dalam penelitian ini yaitu jurnal yang membahas mengenai pelepasan informasi medis, rentang waktu penerbitan jurnal tahun 2010-2020, bahasa yang digunakan adalah Bahasa Indonesia. Kriteria eksklusi untuk menilai jurnal yang akan dipilih dalam penelitian ini yaitu jurnal tidak membahas mengenai kendala pelepasan informasi medis, jurnal hanya menampilkan abstrak atau tidak full text, jurnal tidak dapat di download.

\section{HASIL}

\section{Gambaran Kesesuaian SPO Pelepasan Informasi Medis Kepada Pihak Ketiga di Rumah Sakit}

Berdasarkan penelitian, dari 11 jurnal yang didapatkan hanya terdapat 4 penelitian yang menampilkan hasil kesesuaian SPO pelepasan informasi medis kepada pihak ketiga di rumah sakit. Pelepasan yang sudah sesuai dengan SPO presentasenya diantara 66\%-82\%, sedangkan yang tidak sesuai SPO presentasenya diantara 18\%-34\%. Presentase tertinggi yang sudah sesuai SPO adalah penelitian Faida Eka Wilda yaitu sebesar $82 \%$ dan presentase terendah pada penelitian Siswati, Sri \& Agnesia yaitu sebesar $66 \%$.

\section{Jenis Permintaan Pelepasan Informasi Medis Kepada Pihak Ketiga di Rumah Sakit}

Berdasarkan penelitian, didapatkan jenis permintaan pelepasan informasi medis di rumah sakit yaitu untuk keperluan visum et repertum sebanyak 7 penelitian sehingga presentasenya sebesar $63 \%$, asuransi sebanyak 5 penelitian sehingga presentasenya sebesar $45 \%$ dan pendidikan sebanyak 3 penelitian sehingga presentasenya sebesar 27\%. Sehingga, jenis permintaan pelepasan informasi medis di rumah sakit yang terbanyak adalah permintaan visum et repertum.

Pada visum et repertum, jenis kasus yang sering dibuatkan untuk visum et repertum adalah kasus penganiayaan, kecelakaan, dan pemerkosaan. Untuk pendidikan biasanya digunakan untuk keperluan skripsi dan laporan PKL. Hasil penelitian Pina Lapenia (2019), pada tahun 2014-2016 jumlah permintaan pembuatan visum et repertum sebanyak 146 kasus. Pada penelitian Failus Garin Abtelia (2015), jumlah 
permintaan pembuatan visum pada tahun 2015 sebanyak 21 kasus. Dan penelitian Sinta Puspita Sari (2013), pada tahun 2012 jumlah permintaan visum sebanyak 125 kasus.

\section{Kendala Pelepasan Informasi Medis Kepada Pihak Ketiga di Rumah Sakit}

Berikut ini adalah kendala pelepasan informasi medis kepada pihak ketiga di rumah sakit:

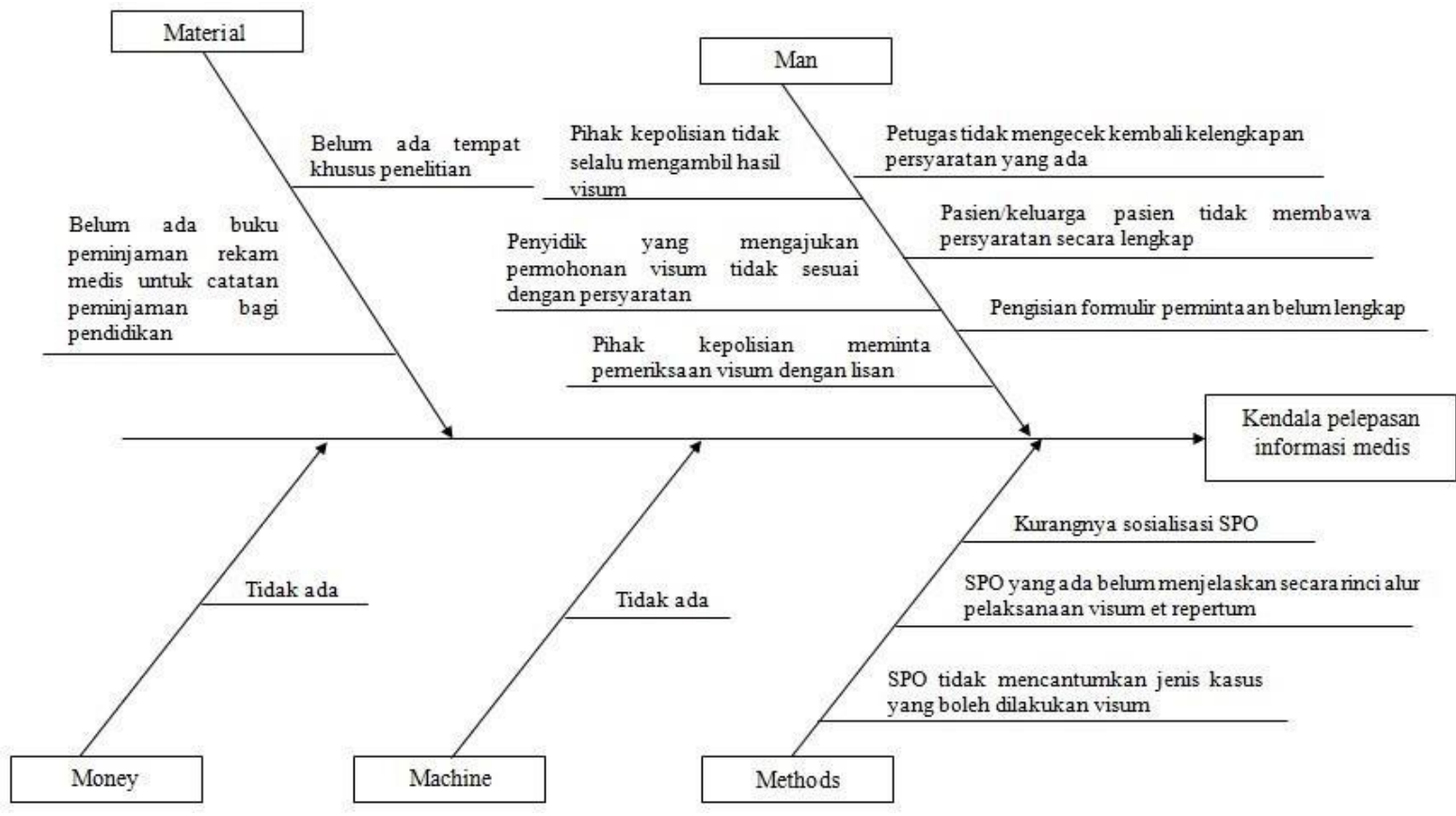

Gambar 1. Diagram Fishbone Kendala Pelepasan Informasi Medis KepadaPihak Ketiga di Rumah Sakit

Berdasarkan penelitian, kendala pelepasan informasi medis yaitu (1) Kendala pada Man adalah petugas rekam medis tidak mengecek kembali kelengkapan persyaratan, pasien/keluarga pasien tidak membawa persyaratan secara lengkap, pengisian formulir permintaan belum lengkap, pihak kepolisian meminta pemeriksaan visum dengan lisan, pihak kepolisian tidak selalu mengambil hasil visum, penyidik yang mengajukan permohonan visum tidak sesuai dengan persyaratan. (2) Kendala pada Methods adalah kurangnya sosialisasi SPO, SPO yang ada belum menjelaskan secara rinci alur pelaksanaan visum et repertum, SPO tidak mencantumkan jenis kasus yang boleh dilakukan visum. (3) Kendala pada Material adalah belum ada tempat khusus penelitian, belum ada buku peminjaman rekam medis untuk catatan peminjaman bagi pendidikan. Kendala dalam pelepasan informasi medis kepada pihak ketiga di rumah sakit dengan menggunakan diagram fishbone yang terbanyak terdapat pada Man terutama pada pasien/keluarga pasien tidak membawa persyaratan secara lengkap. Kendala pelepasan informasi medis yang sering terjadi adalah pasien/keluarga pasien tidak membawa persyaratan secara lengkap dan SPO tidak mencantumkan jenis kasus visum. 


\section{PEMBAHASAN}

\section{Gambaran Kesesuaian SPO Pelepasan Informasi Medis Kepada Pihak Ketiga di Rumah Sakit}

Berdasarkan penelitian, dari 11 jurnal yang didapatkan hanya terdapat 4 penelitian yang menampilkan hasil kesesuaian SPO pelepasan informasi medis kepada pihak ketiga di rumah sakit. Pelepasan yang sudah sesuai dengan SPO presentasenya diantara 66\%-82\%, sedangkan yang tidak sesuai SPO presentasenya diantara 18\%-34\%. Presentase tertinggi yang sudah sesuai SPO adalah penelitian Faida yaitu sebesar $82 \%$ dan presentase terendah pada penelitian Siswati, Adinda \& Agnesia yaitu sebesar $66 \%$.

Pada penelitian Permana \& Rumana (2017), dan Siswati, Adinda \& Agnesia (2018), pelepasan informasi dapat diberikan apabila ada surat permintaan pelepasan secara tertulis dari pasien atau pengadilan dan memperlihatkan identitas asli yang menyebutkan adanya hubungan dari peminta dengan pasien. Sari (2013), dalam permintaan pembuatan visum harus secara tertulis dari pihak kepolisian. Faida (2016), pelepasan informasi dapat diberikan apabila pasien/pihak ketiga mengajukan permintaan informasi medis, petugas nanti akan memberikan formulir pelepasan informasi medis untuk diisi oleh pasien/pihak ketiga lainnya dan akan meminjam kartu identitas pasien untuk di fotokopi. Sehingga hal tersebut sudah sesuai dengan ketentuan pelepasan informasi medis yang telah ditetapkan oleh Depkes yaitu dalam pelepasan informasi medis permohonan dibuat secara tertulis dan informasi medis hanya dapat dikeluarkan dengan adanya surat kuasa dari pasien (Depkes, 2006).

\section{Jenis Permintaan Pelepasan Informasi Medis Kepada Pihak Ketiga di Rumah Sakit}

Berdasarkan penelitian, didapatkan jenis permintaan pelepasan informasi medis di rumah sakit yaitu untuk keperluan visum et repertum sebanyak 7 penelitian sehingga presentasenya sebesar $63 \%$, asuransi sebanyak 5 penelitian sehingga presentasenya sebesar $45 \%$ dan pendidikan sebanyak 3 penelitian sehingga presentasenya sebesar $27 \%$. Sehingga, jenis permintaan pelepasan informasi medis di rumah sakit yang terbanyak adalah permintaan visum et repertum.

Pada visum et repertum, jenis kasus yang sering dibuatkan untuk visum et repertum adalah kasus penganiayaan, kecelakaan, dan pemerkosaan. Untuk pendidikan biasanya digunakan untuk keperluan skripsi dan laporan PKL. Hasil penelitian Pina Lapenia (2019), pada tahun 2014-2016 jumlah permintaan pembuatan visum et repertum sebanyak 146 kasus. Pada penelitian Failus Garin Abtelia (2015), jumlah permintaan pembuatan visum pada tahun 2015 sebanyak 21 kasus. Dan penelitian Sinta Puspita Sari (2013), pada tahun 2012 jumlah permintaan visum sebanyak 125 kasus.

Sehingga jenis permintaan pelepasan informasi tersebut sudah sesuai dengan PERMENKES RI No. 269/MENKES/PER/III/2008 yang menjelaskan bahwa rekam medis dapat dibuka dalam hal untuk kepentingan kesehatan pasien, memenuhi permintaan aparatur penegak hukum dalam rangka penegakan hukum atas perintah pengadilan, permintaan dan/atau persetujuan pasien sendiri, permintaan institusi/lembaga berdasarkan ketentuan perundang-undangan, dan untuk kepentingan 
penelitian, pendidikan dan audit medis sepanjang tidak menyebutkan identitas pasien (Kemenkes, 2008).

\section{Kendala Pelepasan Informasi Medis Kepada Pihak Ketiga di Rumah Sakit Man}

Kendala pelepasan informasi medis kepada pihak ketiga di rumah sakit dari segi man adalah petugas rekam medis tidak mengecek kembali kelengkapan persyaratan yaitu petugas tidak selalu mengecek kembali kelengkapan persyaratan yang ada khususnya pada pengisian surat kuasa dari pihak pasien maupun keluarga pasien karena petugas yang tergesa-gesa mengerjakan tugasnya sehingga yang dilihat hanya terdapat tanda tangan dan nama pasien pada surat kuasa (Faida, 2016). Menurut Hatta, pihak lain selain pasien hanya dapat meminta informasi kesehatan pasien dengan persetujuan pasien. Permohonan harus tertulis dan dilampirkan dengan bukti persetujuan pasien. Surat persetujuan tertulis atau kuasa pasien harus jelas mencantumkan informasi kesehatan mana yang disetujui, kepada siapa surat persetujuan/kuasa tersebut diberikan, hingga sampai kapan surat persetujuan/kuasa tersebut berlaku, dan kapan surat persetujuan/kuasa tersebut ditandatangani (Hatta, 2008).

Pasien/keluarga pasien tidak membawa persyaratan secara lengkap yaitu persyaratan yang sering tidak dibawa pasien maupun keluarga pasien adalah tidak membawa kartu identitas yang sah (Warijan \& 'Afifah, 2019). Menurut PERMENKES RI No. 269/MENKES/PER/III/2008, pihak yang ingin meminta informasi medis harus menunjukkan tanda identitas yang sah (Kemenkes, 2008). Selain itu, persyaratan yang sering tidak dibawa adalah surat pengantar, surat pernyataan pernah dirawat dan kartu keluarga (Tho \& Purnama, 2019).

Pengisian formulir permintaan belum lengkap yaitu ada pada kolom keterangan hubungan keluarga dan tanda tangan peminta (Warijan \& 'Afifah, 2019) dan identitas sosial dari pasien (Faida, 2016). Menurut WHO, bahwa surat permintaan pelepasan informasi medis harus berisi hal-hal meliputi nama lengkap pasien, alamat dan tanggal lahir, nama orang atau lembaga yang meminta informasi, tujuan dan kebutuhan informasi yang diminta, tingkat dan sifat informasi yang akan dikeluarkan, termasuk tanggal keluarnya informasi, dan ditandatangani oleh pasien atau wakil yang sah (misalnya orang tua atau anak) (WHO, 2006).

Pihak kepolisian meminta pemeriksaan visum dengan lisan tanpa adanya surat permintaan tertulis pemeriksaan visum (Lapenia \& Masturoh, 2019). Menurut Depkes (2006), seharusnya pihak rumah sakit menolak semua permintaan pemeriksaan visum secara lisan karena permohonan permintaan informasi harus secara tertulis (Depkes, 2006).

Pihak kepolisian tidak selalu mengambil hasil visum jika bukan untuk kepentingan peradilan sehingga hanya diagendakan oleh pihak rumah sakit atau menjadi arsip rumah sakit (Sari \& Sugiyanto, 2013), (Lapenia \& Masturoh, 2019).

Penyidik yang mengajukan permohonan visum tidak sesuai dengan persyaratan yaitu penyidik bukan berpangkat letnan (Natara \& Sugiyanto, 2014). Menurut Edy Susanto dan Sugiharto, yang dimaksud dengan penyidik adalah penyidik kepolisian dengan pangkat minimal ajun inspektur polisi/pangkat dibawahnya dan menjabat di kapolsek/pegawai negeri yang diberi wewenang (jaksa/hakim) (Susanto \& \& Sugiharto, 2017). 


\section{Methods}

Kendala pelepasan informasi medis kepada pihak ketiga di rumah sakit dari segi methods adalah kurangnya sosialisasi SPO kepada petugas rekam medis (Permana \& Rumana, 2017), (Siswati et al., 2018). Menurut Permenpan No. 15 tahun 2014, dalam proses penerapan standar pelayanan perlu dilakukannya internalisasi dan sosialisasi. Internalisasi diperlukan untuk memberikan pemahaman kepada seluruh jajaran organisasi penyelenggaraan pelayanan. Sosialisasi diperlukan untuk membangun pemahaman dan persamaan persepsi di lingkungan unit penyelenggaraan pelayanan (Pemerintah Indonesia, 2014).

SPO yang ada belum menjelaskan secara rinci alur pelaksanaan visum et repertum karena SPO yang digunakan adalah SPO tentang peminjaman informasi isi rekam medis (Abtelia \& Prasetya, 2015). Menurut Permenpan No. 15 tahun 2014, setiap penyelenggara pelayanan wajib memiliki SPO untuk setiap jenis pelayanan (Pemerintah Indonesia, 2014).

SPO tidak mencantumkan jenis kasus yang boleh dilakukan visum (Sari \& Sugiyanto, 2013), (Natara \& Sugiyanto, 2014), (Rachman \& Sugiyanto, 2010). Tetapi jenis kasus untuk pembuatan visum sudah sesuai dengan teori Edy Susanto dan Sugiharto, yaitu untuk korban hidup, keracunan, perlukaan, dan kejahatan seksual (Susanto \& \& Sugiharto, 2017).

\section{Material}

Kendala pelepasan informasi medis di rumah sakit dari segi material adalah belum ada tempat khusus penelitian dikarenakan keterbatasan ruang yang ada (Istikomah et al., 2020). Menurut PERMENKES RI No. 269/MENKES/PER/III/2008, rumah sakit wajib menyediakan fasilitas yang diperlukan dalam rangka penyelenggaraan rekam medis (Kemenkes, 2008).

Belum ada buku peminjaman rekam medis untuk catatan peminjaman bagi pendidikan yaitu petugas filing tidak menyediakan buku peminjaman untuk rekam medis yang digunakan pendidikan karena biasanya petugas akan melihat kebutuhan penggunaan rekam medis pada surat ijin (Istikomah et al., 2020). Menurut Depkes (2006), buku peminjaman rekam medis wajib dimiliki oleh setiap Unit Rekam Medis guna mengetahui keberadaan dokumen rekam medis yang dipinjam (Depkes, 2006).

\section{KESIMPULAN DAN SARAN}

Berdasarkan 11 jurnal didapatkan presentase kesesuaian SPO pelepasan informasi medis kepada pihak ketiga di rumah sakit adalah $\leq 100 \%$ dan hanya terdapat 4 penelitian yang menampilkan hasil kesesuaian SPO pelepasan informasi medis kepada pihak ketiga di rumah sakit. Pelepasan yang sudah sesuai dengan SPO presentasenya diantara 66\%-82\%, sedangkan yang tidak sesuai SPO presentasenya diantara $18 \%-34 \%$.

Berdasarkan 11 jurnal didapatkan jenis permintaan pelepasan informasi medis di 
rumah sakit yaitu untuk keperluan visum et repertum sebanyak 7 penelitian sehingga presentasenya sebesar $63 \%$, asuransi sebanyak 5 penelitian sehingga presentasenya sebesar $45 \%$ dan pendidikan sebanyak 3 penelitian sehingga presentasenya sebesar $27 \%$.

Kendala dalam pelepasan informasi medis kepada pihak ketiga di rumah sakit dengan menggunakan diagram fishbone yang terbanyak terdapat pada Man terutama pada pasien/keluarga pasien tidak membawa persyaratan secara lengkap.

\section{DAFTAR PUSTAKA}

Abtelia, F. G., \& Prasetya, J. (2015). Tinjauan Pelaksanaan Visum Et Repertum dari Aspek Teori Hukum Kesehatan dan Prosedur Tetap di RSUD Tidar Kota Magelang Tahun 2015. Jurnal Visikes, 17.

Depkes. (2006). Pedoman Penyelenggaran dan Prosedur Rekam Medis Rumah Sakit di Indonesia. Dirjen Bina Pelayanan Medik.

https://www.academia.edu/10918205/Pedoman_Penyelenggaraan_Rekam_Medis _RS_2006

Faida, E. W. (2016). Evaluasi Prosedur Pelepasan Informasi Medis Dalam Menjamin Aspek Hukum Kerahasiaan Rekam Medis Di Rumah Sakit Onkologi Surabaya. Jurnal Manajemen Informasi Kesehatan Indonesia, 4(2), 46-51. https://doi.org/10.33560/.v4i2.131

Hatta, G. (2008). Pedoman Manajemen Informasi Kesehatan di Sarana Pelayanan Kesehatan (G. Hatta (ed.); Revisi 3). Penerbit Universitas Indonesia (UI-PRESS).

Istikomah, F. A., Erawantini, F., \& Putra, D. S. H. (2020). Tinjauan Pelepasan Informasi Rekam Medis Berdasarkan Aspek Hukum Keamanan Dan Kerahasiaan Rekam Medis Untuk Pendidikan Di Rsud Sleman. J-REMI : Jurnal Rekam Medik Dan Informasi Kesehatan, 1(4), 393399.https://doi.org/https://doi.org/10.25047/jremi.v1i4.2169

Kemenkes. (2004). Undang-undang RI No. 29 Tahun 2004 Tentang Praktik Kedokteran.

Kemenkes. (2008). Permenkes RI 269/MENKES/PER/III/2008 Tentang Rekam Medis (Vol. 2008).

Kemenkes. (2009). Undang-undang RI No. 44 Tahun 2009 Tentang Rumah Sakit.

Lapenia, P., \& Masturoh, I. (2019). Tinjauan Pelaksanaan Pelepasan Informasi Medis untuk Keperluan Visum Et Repertum di Rumah Sakit Singaparna Medika Citrautama. Jurnal Manajemen Informasi Kesehatan Indonesia, 7(2), 129-136. https://doi.org/10.33560/jmiki.v7i2.234

Natara, M. I., \& Sugiyanto, Z. (2014). Tinjauan Pelaksanaan Prosedur Pelepasan Informasi Medis Untuk Keperluan Visum Et Repertum dari Aspek Teori di RumahSakit Pantiwilasa Dr Cipto Semarang Tahun 2014. Jurnal Visikes.

Pemerintah Indonesia. (2014). Permenpan No. 15 Tahun 2014 Tentang Pedoman Standar Pelayanan.

Permana, M. H., \& Rumana, N. A. (2017). Tinjauan Proses Pelpasan Informasi Medis kepada pihak Asuransi di RS Muhamadiyah Taman Puring Tahun 2017. Jurnal INOHIM, 5(2), 54-58. https://doi.org/https://doi.org/10.47007/inohim.v5i2.126

Rachman, F., \& Sugiyanto, Z. (2010). Tinjauan Pelaksanaan Prosedur Pelepasan Informasi Medis Untuk Keperluan Visum Et Repertum Dari Aspek Teori Di RST Bhakti Wira Tamtama Semarang. Jurnal Visikes, 9(1), 44-48.

Sari, S. P., \& Sugiyanto, Z. (2013). Tinjauan Pelaksanaan Pelepasan Informasi Medis 
Untuk Keperluan Visum Et Repertum dari Aspek Teori Hukum Kesehatan di RSUD Tugerejo Semarang Tahun 2013. Jurnal Visikes.

Siswati, Adinda, S., \& Agnesia, R. (2018). Tinjauan Pelaksanaan Pelepasan Informasi Medis Kepada Pihak Ketiga Untuk Klaim Asuransi Di Rumah Sakit Muhammadiyah Taman Puring Jakarta Tahun 2018. Medichofrdif Jurnal Rekam Medis, 5(01), 25-32.

Susanto, E., \& \& Sugiharto. (2017). Manajemen Informasi Kesehatan IV: Etika Profesi Dan Hukum Kesehatan (Tahun 2017). Pusat Pendidikan Sumber Daya Manusia Kesehatan.

Tho, I. La, \& Purnama, F. (2019). Analisis Pelepasan Informasi Rekam Medis Dalam Menjamin Aspek Kerahasiaan Rekam Medis Di Rsu Kota Tangerang Selatan. Prosiding: Seminar Nasional Rekam Medis Dan Informasi Kesehatan, 7-16.

Warijan, \& 'Afifah, M. M. N. (2019). Tinjauan Pelaksanaan Pelepasan Informasi Medis. Jurnal Rekam Medis Dan Informasi Kesehatan, 2(1), 27-33. https://doi.org/https://doi.org/10.31983/jrmik.v2i1.4398

WHO. (2006). Medical Records Manual : A Guide for Developing Countries. 